\title{
Малогабаритная тепловизионная камера с микросканированием на базе отечественного матричного КРТ фотоприемника
}

\author{
И.И. Кремис ${ }^{1}$, Р.А. Гладков ${ }^{1}$, А.С. Турбин ${ }^{1}$, Е.А. Крапивко ${ }^{1}$, П.А. Алдохин ${ }^{1}$, В.С. Калинин ${ }^{1}$, \\ В.В. Васильев ${ }^{1}$, А.А. Моисеев ${ }^{1}$ \\ ${ }^{1}$ Филиал ИФП СО РАН «КТИПМ», г. Новосибирск, 630090, ул. Николаева 8, \\ тел: +7(383)330-96-30, эл. почта: igor21738@ngs.ru
}

DOI $10.34077 /$ RCSP2021-46

В Филиале ИФП СО РАН «КТИПМ» разработана и изготовлена тепловизионная камера (ТПК) на базе отечественного матричного КРТ фотоприемника дальнего ИК-диапазона, с микросканированием. Корпус ТПК выполнен в габаритах французской камеры «Сatrine-FC», передняя часть объектива выступает за корпус прибора на 75 мм.

Камера позволяет получать качественное изображение высокого разрешения с использованием малоформатной матрицы. Коррекция неоднородности сигнала фотоприемника осуществляется в автоматическом режиме, с использованием встроенных в тракт оптической системы механизмов в комплексе с алгоритмами калибровки по сигналам сцены.

В состав ТПК входят:

1) Отечественное матричное фотоприемное устройство (ФПУ) производства ИФП СО РАН: материал КРТ; формат 320×256; шаг пикселей 30 мкм; спектральный диапазон 8-12 мкм; микрокриогенная система МСМГ-0,5B-0,5/80 производства НТК «Криогенная техника».

2) Отечественное устройство микросканирования производства Филиала ИФП СО РАН «КТИПМ» [1,2]: циклограмма микроперемещения проекции - четыре точки, по квадрату; смещение проекции - 75 мкм; частота смены полей - 200 Гц.

3) Отечественная высокоэффективная система цифровой обработки сигналов производства Филиала ИФП СО РАН «КТИПМ» [3]: коррекция изображения по сигналам сцены; обнаружение и компенсация сигналов дефектных пикселей фотоприемника по сигналам сцены, в реальном времени (восстановление сигнала сцены дефектных пикселей, таблица дефектов ФПУ не требуется).

4) Впервые в России разработанная и изготовленная в Филиале ИФП СО РАН «КТИПМ» оптическая система с системой электромеханических приводов роторного типа для смены полей зрения, фокусировки и калибровки ТПК.

Технические характеристики ТПК:

- поля зрения: $5,9^{\circ} \times 4,4^{\circ}$ и $21,7^{\circ} \times 17,5^{\circ}$;

- фокусировка: узкое поле - от 3 м до $\infty$; широкое поле - от 1 м до $\infty$;

- напряжение питания: 20-30 B;

- мощность потребления: $34 \mathrm{Bт}$;

- формат выходного тепловизионного изображения: $640 \times 512,50$ Гц;

- габаритные размеры, мм: $310 \times 180 \times 120$.

В докладе будут представлены расширенные результаты измерений параметров тепловизионной камеры.

\section{Лumepamypa}

[1] Кремис И.И. Пат. №2423016. Способ электронной обработки сигналов фотоприемника при формировании изображения и устройство для его осуществления.

[2] Кремис И.И. Фильтрация остаточной неоднородности и дефектов изображения в тепловизорах с использованием микросканирования// Прикладная физика. 2017. № 1. - С. 58 - 64.

[3] Кремис И. И. Устройства микросканирования для тепловизоров диапазона 8-12 мкм на основе вращающихся пластин из $\mathrm{Ge} / /$ Успехи прикладной физики. 2018. № 4. Том 7. - С. 390 - 400. 